\section{A heparinoid cream and tissue fibrinolysis}

Hirudoid is claimed to be a percutaneously active cream, containing a heparinoid (glucosaminoglucan), defined as a mucopolysaccharide polysulphate. It has been in clinical use for many years in the treatment of thrombophlebitis, subcutaneous bleeding, incarcerated haemorrhoids, and burns. A recent double-blind, randomised trial on the effect of the cream in treatment of superficial thrombophlebitis reported a beneficial effect of the cream. ${ }^{1}$

Hirudoid cream has been claimed to stimulate fibrinolysis. ${ }^{25}$ Nevertheless, studies of this effect seem to have given inconclusive results, and hence we studied its influence on tissue fibrinolysis in rat and human skin by a histochemical method modified from Todd. ${ }^{3} 4$

\section{Material, methods, and results}

Hirudoid cream and a placebo cream were kindly supplied by LuitpoldWerk, while inbred rats from a Lister strain of animals with a mean body weight of $200 \mathrm{~g}$ were used.

In the animal experiments an excess of Hirudoid or of placebo cream was thoroughly rubbed into a shaved dorsal skin area of about $9 \mathrm{~cm}^{2}$ in rats anaesthetised intraperitoneally with pentobarbital in a dose of $2 \mathrm{mg} / 100 \mathrm{~g}$ body weight. The skin area was immediately covered with a tight bandage. Groups of four animals were killed at different intervals $(15,45,90 \mathrm{~min}$ and $2,4,6 \mathrm{~h}$, respectively) after application of Hirudoid or placebo cream. Biopsies of skin were immediately frozen. Four anaesthetised, untreated animals were studied.

In the studies on human skin an excess of Hirudoid cream was rubbed into normal skin in regions of planned incisions in patients operated on for hernia or varicose veins. The cream was applied in five patients for $30 \mathrm{~min}$ and in two patients, respectively, for two, four, and $24 \mathrm{~h}$ before operation and covered with a tight bandage. Skin biopsies were taken from the creamtreated skin area and also from five untreated control patients.

The fibrinolytic activity of small specimens of Hirudoid cream; of placebo cream; of the separate constituents of the cream (glycerol, thymol, potassium stearate, lanoline, petroleum jelly, and white wax); and of frozen sections from control, Hirudoid-treated, and placebo-cream-treated rat skin and from control and Hirudoid-treated human skin was examined and semiquantitated by a histochemical method modified from Todd ${ }^{34}$ In a separate experiment specimens of Hirudoid and placebo cream were also incubated with a plasminogen-free fibrin film. The creams were submitted for bacteriological investigation.

In preparations with specimens from both Hirudoid and placebo cream and incubated with either plasminogen-enriched or plasminogen-free fibrin

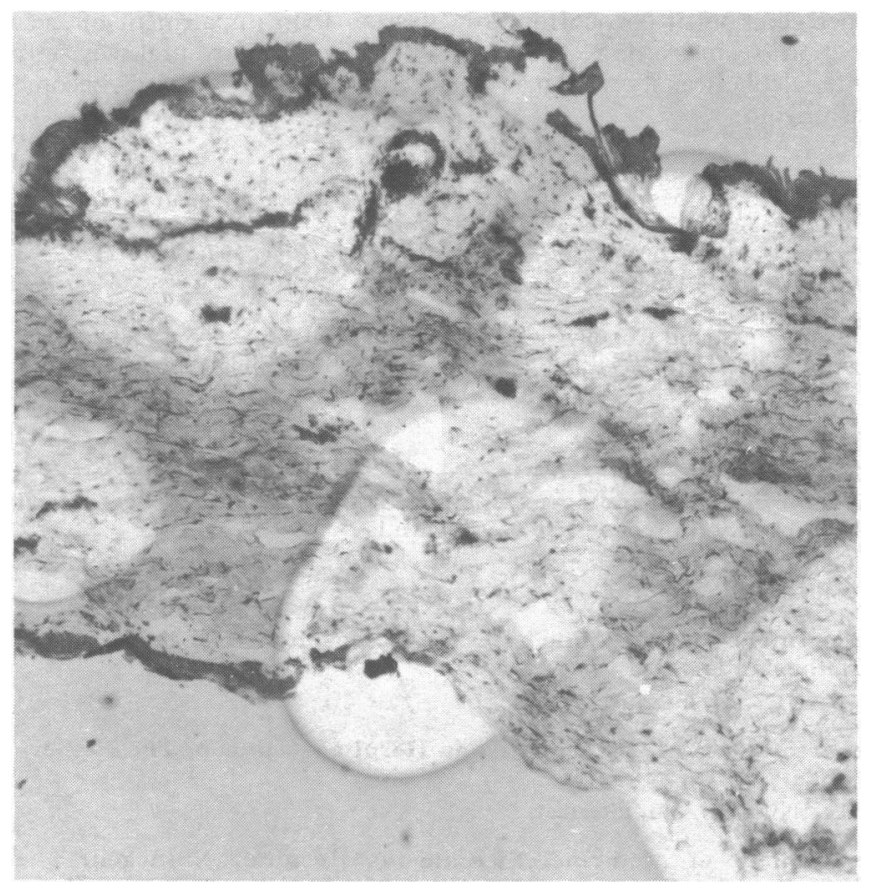

Human skin. Zones of fibrinolysis related to vessels. Incubation time $60 \mathrm{~min}$ (Original magnification $\times 100$ ). films, unstained zones were observed around fragments of cream and were primarily interpreted as lysis of the fibrin film. With further examination of the different constituents of the cream basis, unstained zones were observed around specimens of petroleum jelly, which had apparently influenced the staining of the fibrin film. Tissue fibrinolysis in normal rat skin was low compared with human skin. Fibrinolytic zones in human skin specimens were localized to small vessels (see figure). No stimulation of fibrinolysis was observed either in rat skin or in human skin after application of Hirudoid cream. Both the Hirudoid and the placebo creams were found to be sterile.

\section{Discussion}

In this study no evidence was found for a stimulating effect of Hirudoid cream on tissue fibrinolysis in rat or in human skin. The cream per se did not have any demonstrable plasminogen activating or plasmin activity. A stimulating effect of Hirudoid on blood fibrinolysis, as reported after cutaneous application, should also be detected as an increase of skin tissue fibrinolysis, since circulating plasminogen activators are mainly released from vessel endothelium.

The creams were sterile. No bacterial contamination could therefore be responsible for the observed changes in staining of fibrin films. The results of the present study do not exclude other therapeutic effects of the cream.

1 Mehta, P P, et al, British Medical fournal, 1975, 3, 614.

2 Giarola, P A, and Spreafico, P L, Arzneimittel-Forschung (Drug Research), 1970, 20, 234.

${ }^{3}$ Peterson, H-I, Acta Chirurgica Scandinavica, 1968, Suppl, 394.

4 Risberg, B, Acta Chirurgica Scandinavica, 1975, Suppl. 458.

5 Walther, Ch, et al, Arzneimittel-Forschung (Drug Research), 1969, $19,75$.

Department of Surgery I, Sahlgrenska University Hospital, S-413 45 Göteborg, Sweden

B RISBERG, MD, PHD, senior registrar

H-I PETERSON, MD, PHD, associate professor

\section{Tests of tubal patency: comparison of laparoscopy and hysterosalpingography}

Infertility is regarded as a social stigma in Nigeria and constitutes a major problem. About half the women attending gynaecology clinics complain of primary or secondary infertility. An important part of the investigation of such patients is to determine whether the Fallopian tubes are patent and capable of normal function. I report here the results of examining 86 infertile patients by hysterosalpingography and with use of the laparoscopic methylene blue test.

\section{Patients, methods, and results}

The 86 patients had an average age of 29.5 years (range $19-40$ years) Twenty had primary and 66 secondary infertility. Hysterosalpingography

Results of hysterosalpingography and laparoscopy in the 86 patients. Figures are numbers of patients

\begin{tabular}{|c|c|c|c|c|c|c|}
\hline \multirow{3}{*}{\multicolumn{2}{|c|}{$\begin{array}{l}\text { Bilateral tubal patency } \\
\text { Interstitial tubal occlusion } \\
\text { Unilateral }\end{array}$}} & \multirow{3}{*}{$\ddot{.}$} & \multirow{3}{*}{$\ddot{0}$} & $\begin{array}{c}\text { Hystero- } \\
\text { salpingography }\end{array}$ & \multicolumn{2}{|c|}{$\begin{array}{c}\text { Laparoscopic } \\
\text { methylene blue } \\
\text { test }\end{array}$} \\
\hline & & & & & \multicolumn{2}{|c|}{$\begin{array}{r}33 \\
28\end{array}$} \\
\hline & & & & 8 & $\begin{array}{r}6 \\
22\end{array}$ & \\
\hline Fimbrial occlusion & $\because$ & $\because$ & 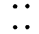 & \multirow{3}{*}{$\begin{array}{rr}3 & 18 \\
15 & \end{array}$} & \multirow{3}{*}{$\begin{array}{r}6 \\
12\end{array}$} & 18 \\
\hline Unilateral & .. & . & $\ldots$ & & & \\
\hline $\begin{array}{l}\text { Bilateral } \\
\text { Combined occlusions }\end{array}$ & $\cdots$ & $\because$ & $\because$ & & & 7 \\
\hline \multirow{2}{*}{\multicolumn{4}{|c|}{$\begin{array}{l}\text { Periadnexal adhesions with or without } \\
\text { tubal occlusion } \\
\begin{array}{l}\text { Fimbrial phimosis in patients with } \\
\text { tubal patency }\end{array} \text {.. }\end{array}$}} & \multirow[t]{2}{*}{4} & & 57 \\
\hline & & & & & & 13 \\
\hline
\end{tabular}

